\title{
ICT Usage Readiness for Private and Public Secondary Schools in Tanzania, a Case of Dodoma Municipality
}

\author{
Augustine Malero \\ College of Informatics and \\ Virtual Education, \\ University of Dodoma, \\ Dodoma, Tanzania
}

\author{
Abbas Ismail \\ College of Mathematical and \\ Natural Science, \\ University of Dodoma, \\ Dodoma, Tanzania
}

\author{
Majuto Manyilizu \\ College of Informatics and \\ Virtual Education, \\ University of Dodoma, \\ Dodoma, Tanzania.
}

\begin{abstract}
The use of ICT in education has been proved to be a key milestone in improving the learning process in different levels of education. To tap this opportunity, the government of Tanzania has implemented a number of projects aimed at introducing and using ICT in different levels of education. There have been similar initiatives in the private institutions as well. However, such initiatives have been facing different challenges particularly on the readiness of using ICT for education for private and public secondary schools. Thus, this study seeks to understand ICT usage readiness between public and private schools. Results from the Pearson's Chi Square distribution reveal that there is a relationship between the types of school with the readiness to adopt the use of ICT in teaching with private school being favored. The study has revealed that private secondary schools in Dodoma municipality are better off than public secondary schools in ICT usage readiness. Challenges for ICT usage readiness affecting the two types of schools are identified, and mitigation mechanisms to close the gap between the two types of schools are proposed. This study is significant in that it informs schools' readiness to use ICT for teaching and administrative use. It also shades light on the comparison of ICT usage between private and public schools.
\end{abstract}

\section{General Terms}

ICT, usage readiness

\section{Keywords}

ICT, usage readiness, private and public secondary schools

\section{INTRODUCTION}

The significance of adopting Information and Communication Technologies (ICTs) in provision of education has been well documented by different authors. Zaman et al. (2001), for example, found that the use of ICT in education improves the learning process by making the learning and teaching an active process connected to real life. Khan et al. (2012) also argues that the use of ICT in schools promotes collaboration and improves students' motivation offering access to information. Therefore, it is not surprising that researchers have predicted an increase in the use of ICTs in classrooms (Becker \& Ravitz, 2001).

Tanzania is aware of the role of ICT and new opportunities which the ICT offers to enhance and improve quality of delivery of education as stipulated in the National ICT Policy of 2003 (Government of Tanzania, 2013). In this regard, the government of Tanzania, through the Ministry of Education and Vocational Training (MoEVT) continues to implement projects aimed at introducing and enhancing use ICT in government teachers' colleges, secondary and primary schools and its agencies (Government of Tanzania, 2007). To strategically introduce and integrate ICT in the education sector, the ministry developed the ICT Policy for Basic Education in 2007 (MoEVT, 2013). The Policy addresses strategic use of ICT in teaching and learning as well as administration and management. Other policies introduced by the government of Tanzania in favor of ICT are the Big Results Now 2014, Education Policy 2014, Science Technology and Innovations (STI) Policy 1996 and the National Research and Development Policy, 2010. Such policies and initiatives prove the recognition of importance of ICT in education and the effort that has been made by the government of Tanzania.

Despite the advantages associated with the use of ICT in secondary schools, the ICT has also created a disparity between the two groups in different parts of the world with private schools being more favored than public schools in the use of ICT. A study by The National Survey on Computer Education in Philippines found that the number of computers owned by private schools is twice as much as what a public school could afford (Government of Philippines, 1996). A similar study by Nchunge et al. (2013) in Thika, Kenya, rated private schools far better than their counterparts in terms of internet connectivity and existence of ICT policy/guidelines. In Tanzania, however, the status of the use between the two groups has not been documented. The lack of such studies leads to poor understanding of the readiness of usage of ICT between private and public secondary schools in Tanzania.

ICT usage readiness is a measure of the degree to which an institution is prepared to partake in electronic activities and, thus, benefit from it (Dada, 2006). This study assesses the readiness of secondary schools in adopting the use of ICT for learning in Dodoma municipality. Dodoma is the capital city of Tanzania located at the center of the country, with a population of 410,956 (National Bureau of Statistics, 2012). The region has continuously underscored low in secondary level national exams. The National Examinations Council of Tanzania (NECTA) results analysis of 2010 ranks Dodoma region in the last position (Government of Tanzania, 2011).This study assesses and compares ICT usage readiness of public and private secondary schools in Dodoma municipality in Tanzania. The research explores the readiness gap between the two types of schools, identify the challenges and propose solutions to close the gap.

The organization of the paper starts with introductory part. The remainder of the paper proceeds as follows; Section 2 describes the methodology used in the study followed by a presentation of the results of the study (Section 3) based on the objectives identified in Section 1. The findings of the study have been discussed in Section 4 . The paper ends by proposing the direction for future research in Section 5. 


\section{METHODOLOGY}

This section presents the methodology that has been adopted to conduct this study. It includes the study design, sampling, data collection techniques, study variables and methods of analysis.

\subsection{Study Design}

A cross-sectional descriptive design was used in the study using both qualitative and quantitative approaches for data collection, analyses and reporting. This design was chosen because it is relatively quick and easy to conduct (no long periods of follow-up), data on all variables is only collected once, multiple outcomes and exposures can be studied. This design is also good for descriptive analyses and for generating hypotheses (Hennekens, 1987).

\subsection{Sampling and Data Collection}

Population in this study included all private and public secondary schools in Dodoma municipal. It consists of a total of 52 schools with 37 government schools and 15 private schools (Dodoma regional report, 2014). Out of the 52 schools, a stratified random sampling was performed and sampled 7 private secondary schools and 9 public secondary schools for the study. From each of these schools data was collected from teachers of schools by filling in survey questionnaires. The questions in the questionnaires focused on identifying schools infrastructure and usage for hosting ICT facilities at these schools.

\subsection{Study variables}

During the analysis, the outcome variable was taken to be the type of school (private vs. public) and the independent variables (covariates) were the use of ICT in content delivery, support obtained by ICT teachers from using ICT, readiness to be empowered with skills and technology and attendance of teachers to ICT trainings. The level of education of the teachers involved in the study were Form Four (Four years secondary education studies), Form six (Two years secondary education study having completed form four studies), certificate, diploma and degree holders. Descriptively, the study looked at availability of electricity, security, computer lab, e-readers, e-books, virtual labs, internet facility, computer for administrative use, staff teaching ICT classes and the existence of electronic systems for students' registration, examination results and attendance.

\subsection{Methods of Analysis}

The data collected during the study were analyzed with a Pearson Chi-square using a statistical package IBM SPSS 22. This method compares the binary outcome and other independent variables.

\section{RESULTS AND DISCUSSION}

This section explains the results obtained during the study. It begins by describing the profile of the respondents and schools surveyed and then proceeds to analyses of the hypotheses. At the end of this section, the critical discussion of the results is given.

\subsection{Profile of Respondents and Schools}

The descriptive profile of the respondents and schools in this study is shown in Table 1 and Table 3, respectively. The respondents are described in terms of sex, age, maximum level of education, number of years in the teaching career and the type of schools involved in the study. Schools are described in terms of their type and availability of the following facilities: electricity, computer laboratory, e- readers, e-books, virtual labs and internet facility. Other metrics include availability of computer for administrative use, electronic systems and staff teaching ICT classes were considered on the type of schools.

From Table 1, it can be observed that the number of male respondents exceeded that of female respondents by 9 . Age wise, the majority of the respondents came from the age group ranging from 26 to 35 years $(64.5 \%)$ while the least represented group was the age group ranges between 18 and 25 years $(6.9 \%)$. It is also noted that the majority of respondents were bachelor degree holders $(75.8 \%)$ followed by diploma $(22.9 \%)$, certificate $(0.9 \%)$ and form six $(0.4 \%)$. Many respondents came from a category of those having less than 5 years of teaching experience $(43.7 \%)$ followed by 11 20 years $(37.2 \%), 11-20$ years $(10.4 \%), 21-30$ years $(5.2 \%)$ and the least represented group was the group with more than 30 years in the teaching carrier description.

Table 2 describes the profile of schools visited during the study. The table shows that all five private schools had existence of electricity where as some public schools did not have electricity. Furthermore, it is noted that private schools had the highest number of schools with computer laboratories, E-books and staff who teach ICT courses than public schools.

Table 1: Description of the respondents in the study

\begin{tabular}{|c|c|c|c|}
\hline Covariate & Response & Frequency & Percentage \\
\hline \multirow[t]{2}{*}{ Sex } & Male & 120 & 51.9 \\
\hline & Female & 111 & 48.1 \\
\hline \multirow[t]{4}{*}{ Age } & $18-25$ & 16 & 6.9 \\
\hline & $26-35$ & 149 & 64.5 \\
\hline & $36-45$ & 43 & 18.6 \\
\hline & Above 45 & 23 & 10.0 \\
\hline \multirow{4}{*}{$\begin{array}{l}\text { Maximum } \\
\text { level of } \\
\text { education } \\
\text { reached }\end{array}$} & Form VI & 1 & 0.4 \\
\hline & Certificate & 2 & 0.9 \\
\hline & Diploma & 53 & 22.9 \\
\hline & First degree & 175 & 75.8 \\
\hline \multirow{5}{*}{$\begin{array}{l}\text { Number of } \\
\text { years in the } \\
\text { teaching } \\
\text { carrier }\end{array}$} & $\begin{array}{l}\text { Less than } 5 \\
\text { years }\end{array}$ & 101 & 43.7 \\
\hline & $5-10$ years & 86 & 37.2 \\
\hline & 11 - 20 years & 24 & 10.4 \\
\hline & 21 - 30 years & 12 & 5.2 \\
\hline & $\begin{array}{l}\text { More than } 30 \\
\text { years }\end{array}$ & 8 & 3.5 \\
\hline \multirow{2}{*}{$\begin{array}{l}\text { Distribution } \\
\text { of the type } \\
\text { of school }\end{array}$} & Public schools & 9 & 44 \\
\hline & Private schools & 7 & 56 \\
\hline
\end{tabular}

It is noteworthy that on testing the first null hypothesis, the hypothesis was rejected because to get the use of ICT tools in content delivery is dependent on the type of school. The corresponding Chi-square value and p-value (Chi square $=11.075, \mathrm{p}<0.05)$ support this decision. In the second hypothesis, the study fails to reject the null hypothesis (Chisquare $=0.214, \mathrm{p}=0.899$ ), and thus, the support obtained from the administration of the school/ municipal/ ministry or any 
other government body is independent of the type of school. The study fails to reject the third hypothesis as well (Chi square $=1.322, \mathrm{p}=0.250$ ) which means, therefore, that readiness to be empowered with skills and technology is independent of the type of school. The last hypothesis is rejected $($ Chi- square $=6.646, \mathrm{p}<0.05)$, and therefore, attending an ICT course by a teacher is dependent of the type of school.

Table 2: Analysis of the covariates on the types of schools and their corresponding $P$-value

\begin{tabular}{|c|c|c|c|c|}
\hline \multirow[t]{2}{*}{ Covariate } & \multirow{2}{*}{$\begin{array}{l}\text { Resp } \\
\text { onse }\end{array}$} & \multicolumn{2}{|c|}{ Type of School } & \multirow{2}{*}{$\begin{array}{l}\text { P- } \\
\text { value }\end{array}$} \\
\hline & & Private & Public & \\
\hline \multirow{2}{*}{$\begin{array}{l}\text { In your teaching, do } \\
\text { you use any ICT } \\
\text { tool to help in } \\
\text { delivering content? }\end{array}$} & Yes & $\begin{array}{l}52 \\
(59.1 \%)\end{array}$ & $\begin{array}{l}52 \\
(36.6 \%)\end{array}$ & \multirow[b]{2}{*}{0.001} \\
\hline & No & $\begin{array}{l}36 \\
(40.9 \%)\end{array}$ & $\begin{array}{l}90 \\
(63.4 \%)\end{array}$ & \\
\hline \multirow{2}{*}{$\begin{array}{l}\text { If you use ICT tools } \\
\text { in delivering, do you } \\
\text { get any support from } \\
\text { the administration of } \\
\text { the school/ } \\
\text { municipal/ ministry } \\
\text { or any other } \\
\text { government body? }\end{array}$} & Yes & $\begin{array}{l}17 \\
(31.5 \%)\end{array}$ & $\begin{array}{l}15 \\
(28.8 \%)\end{array}$ & \multirow[t]{2}{*}{0.899} \\
\hline & No & $\begin{array}{l}32 \\
(59.3 \%)\end{array}$ & $\begin{array}{l}33 \\
(63.5 \%)\end{array}$ & \\
\hline \multirow{2}{*}{$\begin{array}{l}\text { If you do not use } \\
\text { any ICT tool in } \\
\text { delivering content, } \\
\text { are you ready to use } \\
\text { if empowered with } \\
\text { skills and } \\
\text { technology? }\end{array}$} & Yes & $\begin{array}{l}51 \\
(94.4 \%)\end{array}$ & $\begin{array}{l}96 \\
(88.9 \%)\end{array}$ & \multirow[t]{2}{*}{0.250} \\
\hline & No & $\begin{array}{l}3 \\
(5.60 \%)\end{array}$ & $\begin{array}{l}12 \\
(11.1 \%)\end{array}$ & \\
\hline \multirow{2}{*}{$\begin{array}{l}\text { Have you attended } \\
\text { any ICT related } \\
\text { course? OR Have } \\
\text { you taken a course } \\
\text { at the University } \\
\text { /college in ICT? }\end{array}$} & Yes & $\begin{array}{l}59 \\
(84.3 \%) \\
\end{array}$ & $\begin{array}{l}82 \\
(67.2 \%) \\
\end{array}$ & \multirow[t]{2}{*}{0.010} \\
\hline & No & $\begin{array}{l}11 \\
(15.7 \%)\end{array}$ & $\begin{array}{l}40 \\
(32.8 \%)\end{array}$ & \\
\hline
\end{tabular}

In summary, private schools in Dodoma municipality have shown higher level of readiness to use ICT than public schools. This is attributed to the willingness of the teachers in private schools to embrace the use of ICT in content delivery and taking ICT related courses (Table 2). Furthermore, private schools in this municipal have relatively better ICT infrastructure set up than in public schools (Table 3). Such results found in this study concur with other studies in the same area like The National Survey on Computer Education in Philippines (1996) and Nchunge et al(2013).

\subsection{Challenges for ICT Adoption and Proposed Solution}

The study revealed a number of factors hindering the readiness to use ICT in teaching for both public and private schools. Table 4 summarizes the challenges which teachers are facing towards the use of ICT in both private and public secondary schools in Dodoma municipal. It is evident that non existence of ICT infrastructure in both types of these schools is a major factor pulling back the ICT usage readiness in these schools. This factor contributes $71.7 \%$ for private schools and $55.8 \%$ for public schools. Other identified challenges are poor support on ICT initiatives provided to these schools (i.e. $15.1 \%$ for private schools and $32.7 \%$ for public schools), missing required skills (17\% for private schools and $8.7 \%$ for public schools), and lack/poor motivation on using ICT for teaching (i.e. level of motivation is about $1.9 \%$ for private and $5.8 \%$ for public).

The findings reveal that majority of the private school teachers report that their schools do not have enough ICT infrastructures and they do not have the required skills to harness the power of ICT in content delivery. On the other hand, the private school teachers are more motivated and enjoy support from their schools towards ICT usage. To address the gap between the two types of schools readiness towards ICT usage in teaching, the government should set up ICT infrastructure to its schools, train teachers with necessary skills and promote the use of ICT in teaching to increase the motivation to teachers towards using ICT in teaching.

Table 3: Profile of the Schools involved in the study

\begin{tabular}{|c|c|c|c|c|c|c|}
\hline \multirow[b]{2}{*}{ Facility } & \multicolumn{3}{|c|}{ Private School } & \multicolumn{3}{|c|}{ Public School } \\
\hline & $\begin{array}{l}\text { Available } \\
\text { and used }\end{array}$ & $\begin{array}{l}\text { Available } \\
\text { not used }\end{array}$ & $\begin{array}{l}\text { Not } \\
\text { available }\end{array}$ & $\begin{array}{l}\text { Available } \\
\text { and used }\end{array}$ & $\begin{array}{l}\text { Available } \\
\text { not used }\end{array}$ & $\begin{array}{l}\text { Not } \\
\text { available }\end{array}$ \\
\hline Electricity & 4 & 1 & 0 & 5 & 0 & 2 \\
\hline Computer lab & 2 & 0 & 4 & 1 & 1 & 5 \\
\hline E-readers & 0 & 0 & 4 & 0 & 0 & 6 \\
\hline E-books & 1 & 0 & 4 & 0 & 0 & 6 \\
\hline Virtual -lab & 0 & 0 & 4 & 0 & 0 & 6 \\
\hline Internet facility & 1 & 0 & 4 & 2 & 0 & 5 \\
\hline Computer for administrative use & 4 & 0 & 2 & 4 & 0 & 3 \\
\hline Electronic systems & 1 & 0 & 4 & 1 & 0 & 6 \\
\hline Staff teaching ICT classes & 1 & 1 & 4 & 0 & 0 & 7 \\
\hline
\end{tabular}




\section{CONCLUSION}

Education plays a critical role for development of any country in the world as it has been proved to reduce poverty leading the community into prosperity as it gives people different skills needed to handle social, economic, environmental and political issues. The use ICT in education improves teaching and learning at all levels of education. Thus, several governments like Tanzanian have been initiating different initiatives to use ICT in education. However, the challenges on introducing ICT in education could be on readiness of using ICT for schools and individual teachers which is the subject of this study.

The study has revealed that private secondary schools in Dodoma municipality are better off than public secondary schools in ICT usage readiness. The relative high effort to invest and use ICT in teaching and learning $\mathrm{n}$ private schools can be the reason for such readiness. Furthermore, there is relative more efforts on setting up ICT infrastructure in private schools in this municipal than in public schools. Thus, the government should put more emphasis on setting up the ICT infrastructure in private schools so that the benefits enjoyed by private schools can also be felt by public schools. The government should further train teachers in public schools through in-service trainings to equip them with skills on how better they should utilize ICT infrastructure for content delivery.

The study explores well the readiness of the usage of ICT in teaching and learning in both private and public schools in Dodoma Municipality in Tanzania. Such understanding is very important in establishing initiatives on properly utilization of ICT in secondary schools. It provides insight to stakeholders on integrating ICT with education like school administration, teachers and government.

Table 4: Challenges facing teachers in Secondary schools in using ICT for teaching

\begin{tabular}{|l|l|l|}
\hline Challenge & $\begin{array}{l}\text { Private } \\
\text { schools } \\
\text { (Responses } \\
\text { and } \\
\text { percentages } \\
\text { in brackets) }\end{array}$ & $\begin{array}{l}\text { Public } \\
\text { schools } \\
\text { (Responses } \\
\text { and } \\
\text { percentages } \\
\text { in brackets) }\end{array}$ \\
\hline No support is given & $8(15.1)$ & $34(32.7)$ \\
\hline I am not motivated & $1(1.9)$ & $6(5.8)$ \\
\hline $\begin{array}{l}\text { There are no ICT } \\
\text { infrastructure at my school }\end{array}$ & $38(71.7)$ & $58(55.8)$ \\
\hline $\begin{array}{l}\text { I don't have the required } \\
\text { skills }\end{array}$ & $9(17.0)$ & $9(8.7)$ \\
\hline Other reasons & $2(3.8)$ & $3(2.9)$ \\
\hline
\end{tabular}

\section{ACKNOWLEDGEMENT}

Special thanks to the Carnegie-SIG Regional Initiative in Science and Education (RISE) through its competitive fund award for supporting this research. Moreover, this study wouldn't have been possible without a generous support from headmasters, headmistress and teachers of secondary schools in Dodoma municipality.

\section{REFERENCES}

[1] Zaman, M., Shamim, R \& Clement, K (2011) Trends and issues to integrate ICT in teaching learning for the future world of education, International Journal of Engineering \& Technology 11(3) 114-119.

[2] Kahn, H. Hasan, M \& Clement, K. (2012) Barriers to the introduction of ICT into education in developing countries: the example of Bangladesh. International Journal of Instruction, 5 (2) 61-80.

[3] Becker, H. J., \& Ravitz, J. L. (2001) Computer Use by Teachers: Are Cuban's Predictions Correct? Paper presented at the 2001 Annual Meeting of the American Educational.

[4] Government of Tanzania, 2013. National ICT Policy.

[5] Ministry of Education and Vocational Training (MoEVT), 2007. Tanzania ICT Policy for Basic Education.

[6] Government of Tanzania, 2014. Big Results Now (BRN) Initiative.

[7] Government of Tanzania, Education Policy 2014

[8] Government of Tanzania, 1996, Science Technology and Innovations (STI) Policy

[9] Government of Tanzania, 2010. National Research and Development Policy.

[10] Government of Philippines, the National Survey on Computer Education in Philippines (1996).

[11] Nchunge, M., David, S., Maurice, M. and Waweru. (2013). Assessment of ICT Infrastructure on ICT Adoption in Educational Institutions: A Descriptive Survey of Secondary Schools in Kiambu County Kenya. Journal of Computer Science \& Information Technology, 1(1), pp. 32-45.

[12] Dada, D (2006). E-readiness for developing countries: Moving the focus from the environment to the users. The Electronic Journal on Information Systems in Developing Countries. 27, 6, 1-14.

[13] Tanzania National Bureau of Statistics, 2012. The 2012 Population and Housing Census.

[14] Government of Tanzania, Certificate Of Secondary Education Examination (CSEE) - 2011, Report And Analysis Of The Results.

[15] Hennekens, C.H., Buring, J.E. Epidemiology in Medicine. Lippincott Williams \& Wilkins, 1987.

[16] Dodoma Regional report to the President of the United Republic of Tanzania, August, 2014. 